\title{
Erratum to: Right fronto-insular white matter tracts link cognitive reserve and pain in migraine patients
}

\author{
Marian Gomez-Beldarrain ${ }^{1 *}$, Isabel Oroz¹, Begoña Garcia Zapirain², Begoña Fernandez Ruanova ${ }^{3}$, \\ Yolanda Garcia-Chimeno ${ }^{2}$, Alberto Cabrera ${ }^{3}$, Ane Anton-Ladislao ${ }^{4}$, Urko Aguirre-Larracoechea ${ }^{4}$ \\ and Juan Carlos Garcla-Monco ${ }^{1}$
}

After the publication of the original article [1] it was brought to our attention that one of the authors' names was incorrectly reported by the authors. The original spelling reads as 'Yolanda Garcia Fernandez', however, the correct spelling of the name should read as Yolanda Garcia-Chimeno. Please accept the authors' most sincere apologies for this mistake.

\begin{abstract}
Author details
${ }^{1}$ Service of Neurology Hospital de Galdakao-Usansolo, Galdakao, 48960 Vizcaya, Spain. ${ }^{2}$ DeustoTech-LIFE/eVIDA, Universidad de Deusto, Vizcaya, Spain. ${ }^{3}$ Research and Innovation Department, Magnetic Resonance Imaging Unit, OSATEK, Vizcaya, Spain. ${ }^{4}$ REDISSEC, Health Services Research on Chronic Patients Network Research Unit Hospital de Galdakao Usansolo, Galdakao, Vizcaya, Spain.
\end{abstract}

Received: 8 March 2016 Accepted: 8 March 2016

Published online: 11 March 2016

\section{Reference}

1. Gomez-Beldarrain M et al (2016) Right fronto-insular white matter tracts link cognitive reserve and pain in migraine patients. J Headache Pain 17:4

\footnotetext{
* Correspondence: mgomezab@sarenet.es

${ }^{1}$ Service of Neurology Hospital de Galdakao-Usansolo, Galdakao, 48960

Vizcaya, Spain

Full list of author information is available at the end of the article
}

Submit your manuscript to a SpringerOpen ${ }^{\circ}$ journal and benefit from:

- Convenient online submission

- Rigorous peer review

- Immediate publication on acceptance

- Open access: articles freely available online

- High visibility within the field

- Retaining the copyright to your article

Submit your next manuscript at $\gg$ springeropen.com

\section{实}

(c) 2016 Gomez-Beldarrain et al. Open Access This article is distributed under the terms of the Creative Commons Attribution 4.0 International License (http://creativecommons.org/licenses/by/4.0/), which permits unrestricted use, distribution, and reproduction in any medium, provided you give appropriate credit to the original author(s) and the source, provide a link to the Creative Commons license, and indicate if changes were made. 